\title{
CORRIGENDUM
}

\section{THE TEXT OF HORACE, SATIRES 1.4.4: GREEK OLD COMEDY AND LUCILIUS - CORRIGENDUM}

\section{GIACOMO FEDELI}

doi: https://doi.org/10.1017/S0009838817000088, Published by Cambridge University Press 26 April 2017.

In the original version of this article published online 26 April $2017^{1}$ an error was made on page 9 , line 10 . The correct text should read "...the democracy of the sixth and fifth centuries B.C. ...".

The author apologises for this lapsus calami.

${ }^{1}$ G. Fedeli, 'The text of Horace, Satires 1.4.4: Greek Old Comedy and Lucilius', CQ 67 (2017), 1-11. doi:10.1017/S0009838817000088 